\title{
Optimasi E-Commerce dan Kualitas Kuliner Untuk Mendukung Wisata Kuliner di Provinsi Bangka Belitung
}

DOI: https://doi.org/10.32509/abdimoestopo.v5i1.1819

\author{
Giyatmi $^{1}$, Euis Widiati²*, Levyda ${ }^{3}$ \\ ${ }^{1}$ Fakultas Teknologi Pangan dan Kesehatan Universitas Sahid \\ ${ }^{2,3}$ Fakultas Ekonomis dan Bisnis Universitas Sahid \\ J1. Prof. Dr. Soepomo No. 84 Menteng Dalam, Tebet, Kota Jakarta Selatan, Indonesia 12870 \\ *Email Korespondensi: euis_widiati@usahid.ac.id
}

\begin{abstract}
Bangka Belitung Province is a tourist attraction that has the potential for development in culinary tourism. Therefore, it is necessary to design tourism development in harmony with cultural and social development. As a result of creativity, taste, and cultural products that still get attention, local wisdom has always been an inspiration for tourism development, including culinary tourism. Activities carried out include delivering materials and discussions related to promotion using social media (Instagram) and simulation of social media content creation. This community service activity carries the theme of E-Commerce Optimization and Culinary Quality to Support Culinary Tourism in Bangka Belitung Province. Based on the evaluation and monitoring carried out, the recommendations that can be submitted in this activity are assistance for MSMEs should be implemented continuously to improve knowledge and ability in managing the business. Activities can be carried out both by the creative economy and practitioners in their fields and in collaboration with travel agencies to create tour packages that focus on culinary tourism activities.
\end{abstract}

Keywords: Digital Marketing, MSME, Instagram, Food Culinary.

Abstrak - Provinsi Bangka Belitung termasuk salah satu objek wisata memiliki potensi pengembangan
di bidang wisata kuliner. Oleh karena itu, perlu dirancang pengembangan pariwisata yang selaras
dengan pembangunan budaya dan sosial. Sebagai hasil dari kreativitas, rasa dan hasil karya produk
budaya yang masih mendapatkan perhatian, sehingga kearifan lokal selalu menjadi inspirasi
pengembangan pariwisata, termasuk wisata kuliner. Kegiatan yang dilaksanakan meliputi penyampaian
materi dan diskusi terkait promosi menggunakan media sosial (Instagram) dan simulasi pembuatan
konten media sosial. Kegiatan pengabdian masyarakat ini mengusung tema Optimasi E-Commerce dan
Kualitas Kuliner Untuk Mendukung Wisata Kuliner di Provinsi Bangka Belitung. Berdasarkan evaluasi
dan monitoring yang dilakukan maka rekomendasi yang dapat diajukan pada kegiatan ini adalah
kegiatan berupa pendampingan bagi UMKM sebaiknya dilaksanakan secara berkelanjutan untuk
meningkatkan pengetahuan dan kemampuan dalam mengelola usaha. Kegiatan dapat dilakukan baik
oleh bidang ekonomi kreatif maupun praktisi di bidangnya, dibuatkan kerja sama dengan biro
perjalanan wisata untuk membuat paket wisata yang fokus pada kegiatan wisata kuliner.
Kata Kunci: Pemasaran Digital, UMKM, Instagram, Wisata Kuliner 


\section{PENDAHULUAN}

Provinsi Bangka Belitung termasuk salah satu objek wisata memiliki potensi pengembangan di bidang wisata kuliner. Saat ini jumlah UMKM pangan yang bergerak dalam usaha wisata kuliner sudah menunjukkan eksistensinya dalam industri pariwisata. Namun peluang tersebut masih terkendala pada aspek promosi. Saat ini para pelaku UMKM hanya bergantung pada media promosi word-of-mouth yang bersifat konvensional. Sedangkan perkembangan teknologi informasi yang telah berkembang dalam hal media promosi dan pemasaran digital masih belum dioptimalkan. Digital marketing merupakan salah satu solusi tepat bagi usaha mikro, kecil, menengah untuk mengembangkan jaringan pemasaran di dalam negeri maupun internasional. Permasalahannya, pemanfaatan digital marketing oleh pelaku UMKM sangat rendah (Siska et al., 2021).

Wisata kuliner merupakan bagian dari aktivitas berwisata yang diminati para wisatawan. Indonesia dengan kekayaan alam dan budayanya memiliki banyak ragam kearifan lokal yang pada setiap daerah tempat wisata. Menurut Zahrulianingdyah (2018) perlu dicapai konsensus bahwa pengembangan pariwisata tidak boleh mengabaikan aspek budaya masyarakat dan semangat lokal. Oleh karena itu, perlu dirancang pengembangan pariwisata yang selaras dengan pembangunan budaya dan sosial. Sebagai hasil dari kreativitas, rasa dan hasil karya produk budaya yang masih mendapatkan perhatian, sehingga kearifan lokal selalu menjadi inspirasi pengembangan pariwisata, termasuk wisata kuliner.

Tujuan Pengabdian Kepada Masyarakat (PKM) Universitas Sahid dengan pelaku UMKM di Provinsi Bangka Belitung adalah untuk memberikan pelatihan kepada pelaku UMKM untuk melakukan pemasaran digital (digital marketing), mendorong pelaku UMKM memasarkan produknya secara online melalui Instagram, meningkatkan keterampilan pelaku UMKM dalam membuat konten pemasaran digital (digital marketing), dan meningkatkan pemahaman terkait kualitas pangan kuliner.

Kegiatan pengabdian masyarakat diharapkan dapat bermanfaat bagi pelaku UMKM wisata kuliner di Provinsi Bangka Belitung untuk meningkatkan penjualan produknya, dan semakin memperkenalkan keanekaragaman wisata kuliner berbasis kearifan lokal. Menurut (Levyda et al., 2021) branding dapat meningkatkan efisiensi destinasi, sehingga destinasi membutuhkan merek yang dapat meningkatkan kesadaran wisatawan dan citra destinasi. Literasi media sosial bagian dari proses yang harus berkelanjutan seiring dengan perkembangan teknologi informasi, sehingga penting untuk dikuasai oleh para pelaku usaha yang melakukan transaksi jual beli secara online (Riyantini \& Purabaya, 2021).

Berdasarkan penelitian (Kristiana et al., 2018) bahwa strategi yang dapat digunakan dalam pengembangan wisata kuliner adalah dengan membuat kawasan wisata kuliner yang khusus menawarkan kuliner khas Bangka Belitung, kemudian mengembangkan kerja sama dengan Pemerintah Daerah dari kota lain untuk mempromosikan kuliner di Provinsi Bangka Belitung, hingga memanfaatkan teknlogi informasi dalam pemasaran digital. Promosi pada media sosial merupakan bagian dari pemasaran digital, seperti yang disampaikan (Akhmad, 2015) media sosial merupakan hasil pengembangan teknologi jaringan baru berbasis internet, yang memudahkan setiap orang untuk berkomunikasi, berbagi, dan membentuk jaringan online. 


\section{METODE PELAKSANAAN}

Pelaksanaan kegiatan PKM dalam program pengabdian masyarakat berbasis penelitian dilakukan pada tanggal 13 Desember 2021 bekerja sama dengan Dinas Pariwisata Bidang Ekonomi Kreatif Kota Pangkalpinang, yang diselenggarakan di Bangka Botanical Garden. Model kegiatan yang dilaksanakan yaitu model keterampilan kerja (skill training for business) meliputi penyampaian materi, diskusi terkait promosi menggunakan media sosial (Instagram), praktik simulasi/ peragaan pembuatan konten media sosial, latihan praktik, hingga simulasi bisnis.

Kegiatan pengabdian masyarakat ini mengusung tema Optimasi E-Commerce dan Kualitas Kuliner Untuk Mendukung Wisata Kuliner di Provinsi Bangka Belitung. Secara rinci pelatihan dan pendampingan mengenai digital marketing dilakukan melalui tahapan seperti pada Tabel 1.

Tabel 1. Rincian Kegiatan Pengabdian Masyarakat Hari ke-1 Pelatihan dan Pendampingan

\begin{tabular}{|c|c|c|}
\hline No & Tahapan Kegiatan & Uraian Kegiatan \\
\hline \multirow[t]{7}{*}{1} & Persiapan kegiatan & - Permohonan izin kegiatan pengabdian masyarakat kepada \\
\hline & & Dinas Pariwisata Bidang Ekonomi Kreatif Kota \\
\hline & & Pangkalpinang \\
\hline & & - Pengurusan administrasi (surat-menyurat) \\
\hline & & - Survey tempat pengabdian masyarakat yaitu di Bangka \\
\hline & & Botanical Garden (BBG) \\
\hline & & - Persiapan alat dan bahan, transportasi serta akomodasi \\
\hline \multirow[t]{5}{*}{2} & Penyampaian materi & $\begin{array}{l}\text { - Pembukaan dan perkenalan dengan para pelaku UMKM } \\
\text { yang menjadi sasaran kegiatan }\end{array}$ \\
\hline & & - Pengerjaan pre-test bagi peserta PKM \\
\hline & & - Penyampain materi dan diskusi/tanya jawab \\
\hline & & - Simulasi dan praktik \\
\hline & & - Pengerjaan post-test bagi peserta PKM \\
\hline \multirow[t]{3}{*}{3} & Penutupan & - Pemberian bantuan pendukung usaha (blender) \\
\hline & & - Foto bersama dengan peserta UMKM \\
\hline & & - Pembuatan laporan kegiatan \\
\hline
\end{tabular}
Hari ke-2 Kunjungan Kepada UMKM Wisata Kuliner

\begin{tabular}{|c|c|c|}
\hline No & Tahapan Kegiatan & Uraian Kegiatan \\
\hline 1 & Persiapan kegiatan & $\begin{array}{l}\text { - Koordinasi dengan Dinas Pariwisata Bidang Ekonomi } \\
\text { Kreatif Kota Pangkalpinang } \\
\text { - Pengurusan administrasi (surat-menyurat) }\end{array}$ \\
\hline 2 & Kunjungan & $\begin{array}{l}\text { - Kunjungan ke kantor Dinas Pariwisata Kota } \\
\text { - } \text { Pangkalpinang } \\
\text { - } \text { Kinjungan kepada pelaku UMKM Wisata Kuliner } \\
\text { - } \text { Foto bersama dengan pelaku UMKM } \\
\text { - Berpamitan dengan pelaku UMKM dan Dinas Pariwisata } \\
\text { - Pembuatan laporan kegiatan }\end{array}$ \\
\hline
\end{tabular}




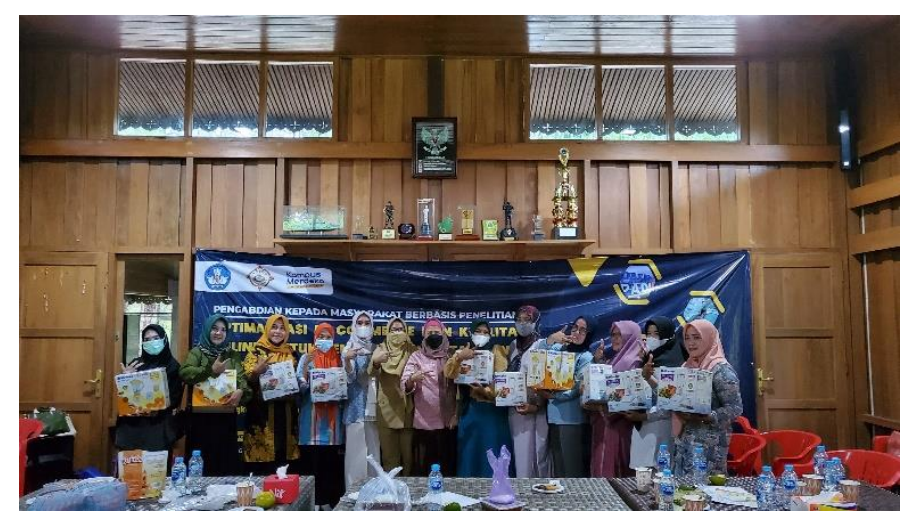

Gambar 1. Foto Bersama Peseta PKM

Sumber: Dokumentasi pribadi

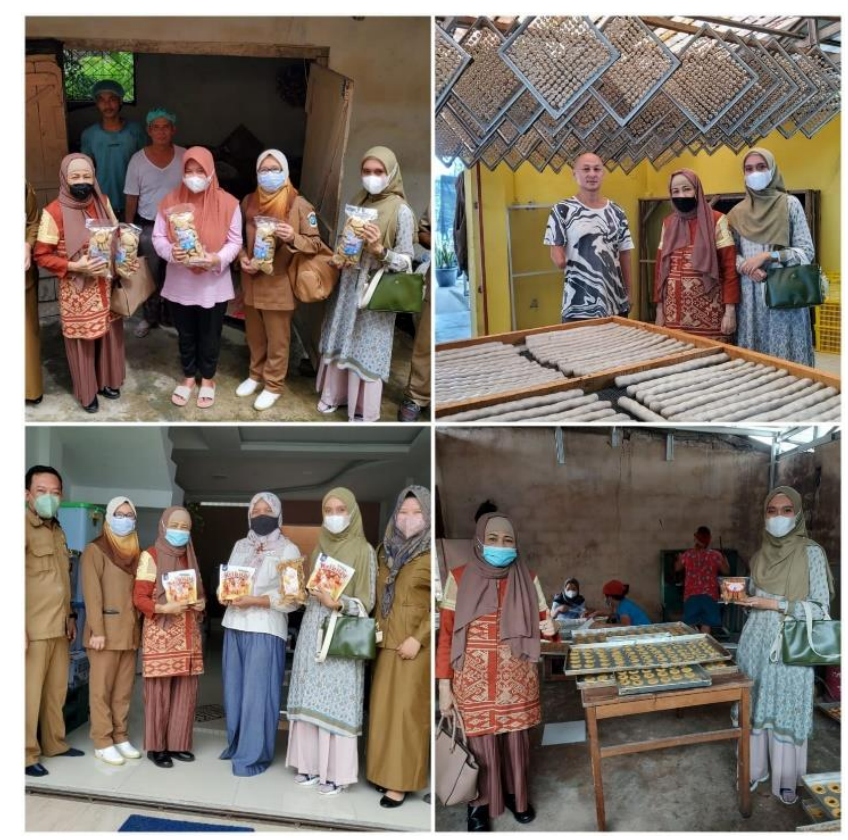

Gambar 2. Kunjungan Kepada UMKM

Sumber: Dokumentasi pribadi 


\section{HASIL PENEMUAN DAN DISKUSI}

Menurut (Agusetyaningrum et al., 2016) faktor pendukung pada seni manajemen pengembangan UMKM kuliner yaitu perijinan, pelatihan, pemasaran serta paguyuban. Berdasarkan hasil penelitian bahwa pameran dan media sosial yaitu pada teknik pemasaran sangat membantu pelaku UMKM kuliner pada memperkenalkan produknya ke masyarakat. Salah satu cara yang bisa dipilih oleh pelaku UMKM yaitu dengan upaya pemasaran digital sebagai hal utama dalam hal peningkatan pada pemasaran media sosial, iklan online, video marketing, search engine marketing (SEM), serta pengelolaan web. Dengan menggunakan pemasaran digital dalam aktivitas bisnis, UMKM memiliki peluang pasar yang luas serta berkesempatan mendapatkan pelanggan baru. Selain itu, konsumen menjadi lebih mudah memperoleh data yang dibutuhkan secara online (Mulyani, 2021).

Pada kegiatan pengabdian masyarakat, pelatihan yang diberikan yaitu terkait keterampilan membuat konten promosi pada media sosial Instagram menggunakan aplikasi Canva. Selain itu simulasi dan praktik membuat akun Instagram Bisnis. Metode kombinasi antara materi dan praktik digunakan sebagai upaya untuk memfasilitasi tahapan pelatihan dan pendampingan bagi peserta PKM untuk dapat berpartisipasi aktif secara langsung. Menurut (Sufa et al., 2020) wisata kuliner tidak hanya menjual produk makanan dan minuman kepada wisatawan, tetapi juga memberikan pengalaman yang berharga bagi wisatawan dari makanan dan minuman yang mereka cicipi atau beli.

Dalam pelaksanaan perdagangan e-commerce, pelaku UMKM harus dapat terus menerus mengirimkan dan mempromosikan produk. Hal tersebut dapat dilakukan dengan langkah-langkah insentif dalam memasarkan produk melalui penggunaan pemasaran digital dan e-commerce, hingga penggunaan media sosial untuk menghubungi pembeli secara langsung (Supriyani \& Untari, 2021). Untuk mengetahui tingkat keberhasilan kegiatan pengabdian masyarakat ini, dapat dilihat pada Tabel 2.

Tabel 2. Sebaran Data Peserta PKM

\begin{tabular}{clclc}
\hline \multirow{2}{*}{ No } & \multirow{2}{*}{ Nama Peserta } & \multicolumn{3}{c}{ Keterangan } \\
\cline { 3 - 5 } & & Mulai Usaha & \multicolumn{1}{c}{ Jenis Usaha } & Instagram Usaha \\
\hline 1. & Lissaandra Purnami & 2017 & UMKM Kuliner & $\sqrt{ }$ \\
2. & Rospah Ediawati & 2015 & UMKM Kuliner & $\sqrt{ }$ \\
3. & Asri Yani & 2016 & UMKM Kuliner & \\
4. & Sundari & 2015 & UMKM Kuliner & $\sqrt{ }$ \\
5. & Fitri Andari & 2019 & UMKM Kuliner & $\sqrt{ }$ \\
6. & Sulfiani Rahma & 2019 & UMKM Kuliner & \\
7. & Deska Yulan Sari & 2015 & UMKM Kuliner & $\sqrt{ }$ \\
8. & Mardina & 2015 & UMKM Kuliner & \\
9. & Era Mayasari & 2016 & UMKM Kuliner & \\
\hline
\end{tabular}

Berdasarkan informasi pada tabel di atas dapat diketahui bahwa belum semua peserta pelaku usaha memiliki akun Instagram yang khusus digunakan untuk aktivitas usahanya. Maka pada kegiatan pengabdian masyakarat sangat sesuai dengan kebutuhan pelaku UMKM saat ini untuk meningkatkan kemampuan dan keterampilannya dalam bersaing di era bisnis digital saat ini. Pada kesempatan tersebut narasumber yang sekaligus bertindak sebagai trainer juga memberikan pendampingan bagi para pelaku UMKM yang belum memiliki akun Instagram untuk kemudian membuat Instagram bisnis bagi usahanya. Selain itu peserta diberikan pelatihan untuk membuat konten feed dan story Instagram agar lebih menarik audience dengan menggunakan aplikasi Canva, seperti yang dapat dilihat pada Gambar 3. 


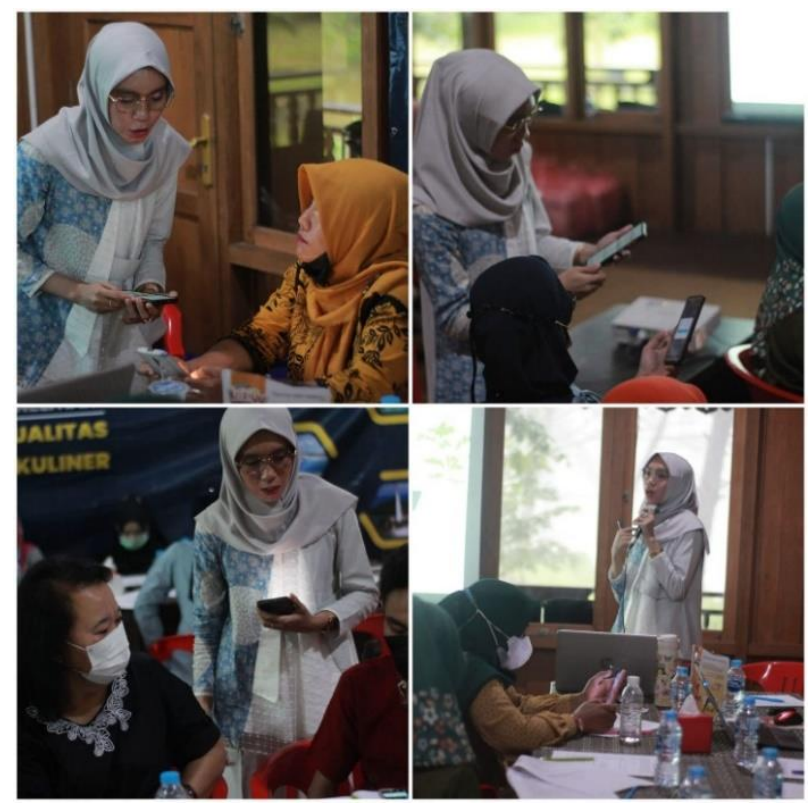

Gambar 3. Pelatihan dan Pendampingan Membuat Instagram Bisnis Sumber: Dokumentasi pribadi

Peserta PKM juga diberikan pemahaman mengenai materi terkait pengelolaan Instagram Bisnis. Untuk melihat dampak pelatihan dan materi yang disampaikan maka peserta diberikan tes pada awal dan akhir sesi. Berikut Gambar 4 di bawah ini dapat dilihat evaluasi pemahaman materi peserta PKM.

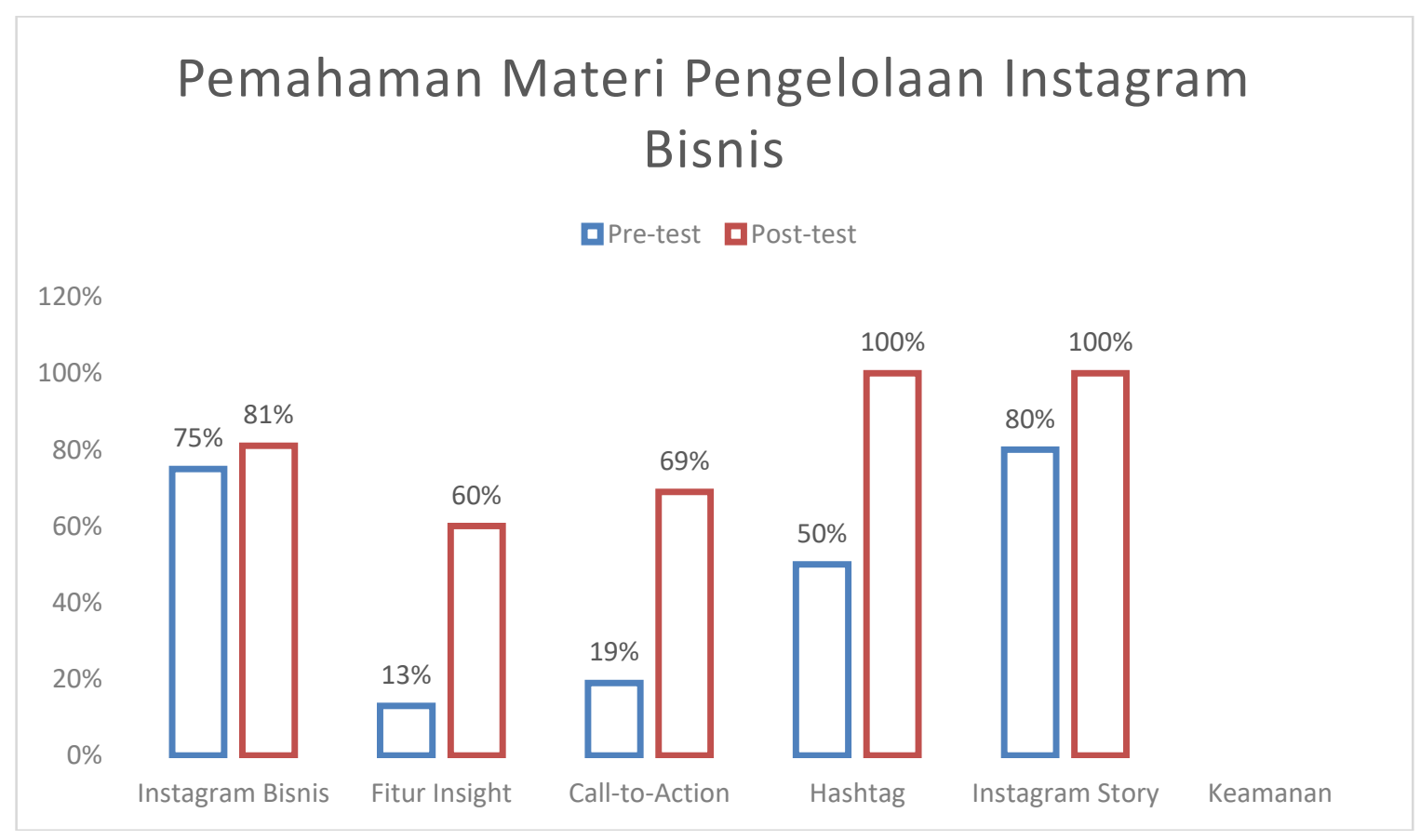

Gambar 4. Evaluasi Pemahaman Materi Pelatihan

Sumber: Data diolah dari pre-post test

Berdasarkan hasil evaluasi pemahaman materi pelatihan, secara umum para peserta telah mendapatkan peningkatan pemahaman. Dapat dilihat pada nilai pre-test dan post-test tersebut di atas saat ini peserta sudah lebih memahami bahwa akun Instagram Bisnis memiliki 
beberapa fitur yang berbeda dengan Instagram personal. Selain itu peningkatan pemahaman yang cukup tinggi yaitu sebesar 57\% terdapat pada aspek pemahaman terkait fitur insight yang dapat digunakan untuk mengetahui engagement follower dan demographic audience.

Selain itu nilai kenaikan yang tinggi lainnya terlihat pada pemahaman terkait penggunaan kalimat pada bio Instagram, yaitu call-to-action yang bermanfaat untuk memberikan informasi utama terkait tempat usaha (toko). Peserta PKM mengalami kenaikan pemahaman sebesar 50\% dalam menentukan contoh kalimat yang bersifat call-to-action. Dalam konten feed Instagram terdapat strategi yang dapat digunakan untuk dapat memudahkan konsumen calon pembeli menemukan toko online, yaitu dengan penggunaan tagar (hashtag). Adapun batasan jumlah penggunaan hashtag yang dinilai efektif yaitu sebanyak empat dalam setiap konten yang dipublikasikan pada feed.

Fitur lainnya yang dapat digunakan sebagai promosi pada pemasaran digital menggunakan Instagram adalah dengan Instagram story. Fitur tersebut dinilai sangat efektif untuk menyampaikan informasi yang sifatnya sementara, namun dapat menarik perhatian audience karena akan membuat follower untuk tetap setia menyaksikan informasi pada konten yang dipublikasikan. Sehingga calon konsumen yang membutuhkan informasi terkait promosi produk dari sebuah toko online akan memutuskan untuk mengikuti akun Instagram toko tersebut. Seperti yang disampaikan (Ziliwu \& Simanjuntak, 2021) bahwa faktor pendorong untuk mengembangkan UMKM Kuliner adalah dengan meningkatkan inovasi produk dan fokus pada branding produk dan pemasarannya.

\section{SIMPULAN}

Kegiatan pengabdian masyarakat dengan tema Optimasi E-Commerce dan Kualitas Kuliner Untuk Mendukung Wisata Kuliner di Provinsi Bangka Belitung ini sangat bermanfaat bagi para pelaku UMKM. Karena telah memberikan solusi dan media dalam pengembangan perekonomian daerah melalui kewirausahaan lokal. Berdasarkan evaluasi dan monitoring yang dilakukan maka rekomendasi yang dapat diajukan pada kegiatan ini adalah kegiatan berupa pendampingan bagi UMKM sebaiknya dilaksanakan secara berkelanjutan untuk meningkatkan pengetahuan dan kemampuan dalam mengelola usaha. Kegiatan dapat dilakukan baik oleh bidang ekonomi kreatif maupun praktisi di bidangnya, dan kemudian daibuatkan kerja sama dengan biro perjalanan wisata untuk membuat paket wisata yang fokus pada kegiatan wisata kuliner.

\section{Ucapan Terima Kasih}

Dalam kegiatan pengabdian masyarakat ini penulis mengucapkan terima kasih kepada semua pihak yang berperan dan mendukung pelaksanaannya kegiatan. Terima kasih kepada Kementerian Pendidikan, Kebudayaan, Riset dan Teknologi atas Bantuan Pendanaan Program Penelitian Kebijakan Merdeka Belajar Kampus Merdeka dan Pengabdian Masyarakat Berbasis Hasil Penelitian dan Purwarupa PTS, Dinas Kota Pangkalpinang, dan para pelaku UMKM Provinsi Bangka Belitung.

\section{Daftar Pustaka}

Agusetyaningrum, V., Mawardi, M. K., \& Pangestuti, E. (2016). Strategi Pengembangan Usaha Kecil Dan Menengah (Ukm) Untuk Meningkatkan Citra Kota Malang Sebagai Destinasi Wisata Kuliner (Studi Pada UKM Berbasis Kuliner Kota Malang). Jurnal Administrasi Bisnis (JAB), 38(2), 105-111.

Akhmad, K. A. (2015). Pemanfaatan Media Sosial bagi Pengembangan Pemasaran UMKM 
(Studi Deskriptif Kualitatif pada Distro di Kota Surakarta). Duta.Com Journal, 9(1), 4354. http://journal.stmikdb.ac.id/index.php/dutacom/article/view/17

Kristiana, Y., Suryadi, M. T., \& Sunarya, S. R. (2018). Eksplorasi Potensi Wisata Kuliner Untuk Pengembangan Pariwisata Di Kota Tangerang. Khasanah Ilmu: Jurnal Pariwisata Dan Budaya, 9(1), 18-23. https://doi.org/10.31294/khi.v9i1.3604

Levyda, L., Ratnasari, K., \& Giyatmi, G. (2021). Local Food as a Tourism Brand for the Regional Area: The Case in Bangka Belitung Indonesia. Review of Integrative Business and Economics Research, 10(2), 66-74.

Mulyani, Y. S. (2021). E-Commerce Solusi Pemasaran UMKM Dalam Mengembangkan Industri Pariwisata Di Tengah Pademi Covid-19 (Studi Kasus UMKM di Kota Tasikmalaya). Khasanah Ilmu: Jurnal Pariwisata Dan Budaya, 12(2), 131-141. https://doi.org/10.31294/khi.v12i2.11293

Riyantini, R., \& Purabaya, R. H. (2021). Sehat Bermedia Sosial Saat Pandemi Covid-19 Melalui Pelatihan Daring Bagi Ibu Rumah Tangga. ABDI MOESTOPO: Jurnal Pengabdian Pada Masyarakat, 4(02), 80-87. https://doi.org/10.32509/abdimoestopo.v4i02.1451

Siska, E., Atmojo, D., \& Prapto, W. (2021). Pelatihan Digital Marketing Pada Marketplace Sebagai Strategi Peningkatan Penjualan Produk UMKM Pulo Gadung Jakarta Timur Pada Masa New Normal. Jurnal Abdimas Perbanas, 2(2), 59-75.

Sufa, S. A., Subiakto, H., Octavianti, M., \& Kusuma, E. A. (2020). Wisata Gastronomi Sebagai Daya Tarik Pengembangan Potensi Daerah Kabupaten Sidoarjo. Mediakom: Jurnal Ilmu Komunikasi, 4(1), 75-86. https://doi.org/10.35760/mkm.2020.v4i1.2497

Supriyani, N., \& Untari, D. (2021). Strategi Dan Pemanfaatan Media Sosial Usaha Kecil Dan Menegah (Umkm) Bertahan Di Tengah Pandemi Covid-19. Ekono Insentif, 15(1), 1-9. https://doi.org/10.36787/jei.v15i1.419

Zahrulianingdyah, A. (2018). Kuliner Sebagai Pendukung Industri Pariwisata Berbasis Kearifan Lokal. Teknobuga, 6(1), 1-9. https://doi.org/10.1529/jtbb.v6i1.16667

Ziliwu, G. E. K., \& Simanjuntak, M. (2021). Analisis Peningkatan Kinerja UMKM Kuliner Dastinasi Wisata Melalui Strategi Comparative Advantage dengan pendekatan The House Model Studi Empiris Toba Indonesia Prosiding Seminar Nasional Ekonomi-Bisnis Indonesia yang terdiri dari berbagai keberagaman kek. Prosiding Seminar Nasional Ekonomi Bisnis, 104-119. 